\title{
Influence of diet on stable carbon isotope composition in otoliths of juvenile red drum Sciaenops ocellatus
}

\author{
James Nelson $^{1, *}$, Chad W. Hanson ${ }^{1}$, Christopher Koenig ${ }^{2}$, Jeff Chanton ${ }^{1}$ \\ ${ }^{1}$ Department of Earth, Ocean and Atmospheric Sciences, Florida State University, Tallahassee, Florida 32306, USA \\ ${ }^{2}$ FSU Coastal and Marine Laboratory, 3618 Coastal Highway 98, St. Teresa, Florida 32358-2702, USA
}

\begin{abstract}
Stable carbon isotope values of otoliths can provide long-term records of the environmental conditions experienced by fish. However, because otoliths contain carbon from metabolic sources, it is necessary to determine the proportion of metabolically derived carbon to properly interpret otolith $\delta^{13} \mathrm{C}$ values. To evaluate the relative influence of dietary carbon and the dissolved inorganic carbon (DIC) of ambient seawater on the $\delta^{13} \mathrm{C}$ isotopic composition of fish otoliths, juvenile red drum $S c i-$ aenops ocellatus were raised for 6 and 9 mo in tanks with flow-through ambient seawater and fed diets differing by $2.1 \%$ o $(\mathrm{p}<0.001)$ in carbon isotope composition $\left(\delta^{13} \mathrm{C}\right)$. At the end of the experiment, muscle tissue from the 2 treatments reflected the isotopic composition of the diets and differed by $2.1 \%$ o $(\mathrm{p}<0.001)$. Muscle tissue from both groups was enriched by $1.5 \%$ in ${ }^{13} \mathrm{C}$ relative to the respective diets. The carbon isotope values of otoliths were enriched by $\sim 16$ to $17 \%$ relative to the respective diets, indicating that DIC was the dominant source (85 to $92 \%$ ) for otolith carbon relative to carbon derived from diet. However, otoliths from the 2 treatments differed by $1.26 \%$ and expressed $60 \%$ of the difference in the isotope values of the diets. This result indicates that the nutritional characteristics of food may be a factor influencing the incorporation of metabolic carbon in the otolith. This is one of the first studies to provide evidence that the nutritional value of food influences otolith $\delta^{13} \mathrm{C}$ value.
\end{abstract}

KEY WORDS: Otoliths $\cdot$ Stable isotopes $\cdot$ Red drum $\cdot$ Sciaenops ocellatus

Resale or republication not permitted without written consent of the publisher

\section{INTRODUCTION}

Fish otoliths, or ear stones, are primarily composed of calcium carbonate (aragonite). They are found in the otic capsule of the cranium of fish and function in hearing, equilibrium, and angular acceleration. Otoliths grow by accretion, incorporating elements from the surrounding endolymph. Because these elements remain in the otolith throughout the life of the fish they are permanent records containing valuable information that can be used to infer life-history characteristics (Degens et al. 1969, Radtke et al. 1998a, Schwarcz et al. 1998).

The stable isotope composition of otoliths $\left(\delta^{13} \mathrm{C}\right.$ and $\delta^{18} \mathrm{O}$ ) can provide valuable information on the environmental conditions experienced by fish (Radtke et al. 1996, 1998b, Das et al. 2000, Begg \& Weidman 2001). The incorporation of $\delta^{18} \mathrm{O}$ into the otoliths of fish is tem- perature dependent; therefore, the $\delta^{18} \mathrm{O}$ composition of otoliths can be used to reconstruct ambient seawater temperatures experienced during the lifetime of the fish (Høie et al. 2004). Many studies have used oxygen and carbon isotopes to delineate fish populations and stocks (Gao \& Beamish 1999, Newman et al. 2000, Bastow et al. 2002). However, a number of factors complicate interpretation of $\delta^{13} \mathrm{C}$ data from otoliths.

In reference to ${ }^{13} \mathrm{C}$, seminal studies by Degens et al. (1969) suggest that otolith aragonite is deposited in isotopic equilibrium with surrounding seawater. But more recent work demonstrates the incorporation of aragonite into fish otoliths from 2 sources: endogenous and exogenous. Endogenous sources are derived from catabolic processes, and exogenous sources are derived from dissolved inorganic carbon (DIC) in the external milieu entering the blood through the gills and through 
the digestive tract, mainly as bicarbonate (Høie et al. 2003, Solomon et al. 2006). A poor understanding of the proportional contribution of each source and associated enrichment factors has limited the usefulness of otolith $\delta^{13} \mathrm{C}$ values in fish ecology. Several studies have quantified the proportion of each carbon source, DIC and food, and, in most cases, the $\delta^{13} \mathrm{C}$ values of the otoliths reflect $\sim 80 \%$ DIC and $\sim 20 \%$ food (Weidman \& Millner 2000, Høie et al. 2003, Solomon et al. 2006, Tohse \& Mugiya 2008). To our knowledge, the only study that has estimated the associated fractionation factors from the carbon sources to the otolith (Solomon et al. 2006) found otoliths to be enriched by 2.7 to $3.6 \%$ relative to the fish's diet.

In the present study, we attempted to validate these estimates by holding red drum Sciaenops ocellatus (Pisces: Sciaenidae) under isotopically identical water conditions while feeding them isotopically distinct diets. To ensure the fish equilibrated to the diets, we determined the $\delta^{13} \mathrm{C}$ values of red drum muscle tissue, which reflects the value of each treatment diet (DeNiro \& Epstein 1976, Nelson et al. 2010). We hypothesized that the $\delta^{13} \mathrm{C}$ values of the juvenile red drum otoliths reflect to some degree the differences in the $\delta^{13} \mathrm{C}$ values of the food the fish were fed during the experiment. Our objectives were to quantify the degree to which $\delta^{13} \mathrm{C}$ differences in diet would be reflected in otolith $\delta^{13} \mathrm{C}$ and to use these differences to calculate the relative contributions of DIC and respired dietary carbon to otolith carbon.

\section{MATERIALS AND METHODS}

Experimental design. Approximately 500 red drum (39 d old) were obtained from the Stock Enhancement Research Facility (Florida Fish and Wildlife Conservation Commission) in Port Manatee, Florida, on August 10, 2001. Fish were acclimated to laboratory conditions at the Florida State University Coastal and Marine Laboratory (FSUMCL) in 16 rectangular flow-through saltwater tanks (210 l volume) for several weeks and fed a standard prepared diet until they were able to consume their prescribed diets (Fig. 1). During the first week of the acclimation period, the fish were fed their accustomed commercial diet (Ziegler Salmon Starter, Burris; $\delta^{13} \mathrm{C} \approx-21 \%$ o). Fish were then fed another commercial hatchery feed (AquaMax Fingerling Starter 300, Purina Nutritional International, $\delta^{13} \mathrm{C} \approx-20 \%$ ) for $39 \mathrm{~d}$ until they were able to consume ground fishtissue. On September 17, 2001 (Day 1 of the experiment), the fish were given 2 diets differing in carbon stable isotope ratios. The fish in Treatment A continued with the AquaMax feed. The fish in Treatment B were switched to a diet that consisted of muscle tissue from the pinfish Lagodon rhomboides (family: Sparidae, $\delta^{13} \mathrm{C} \approx-17 \%$ ), a common inshore fish in NW Florida. The majority of the pinfish used were collected from Apalachicola Bay. Some pinfish were purchased from local seafood and bait dealers who harvested in the bay and nearby waters. Fresh pinfish were kept frozen until feeding time, when they were thawed, filleted, and ground or cut into pieces. Fish were fed ad libitum with AquaMax or minced pinfish fillets once each day.

The 16 tanks used for this experiment had average flow rates of $782.01 \mathrm{~h}^{-1}$ (range $=599.9$ to $851.71 \mathrm{~h}^{-1}$ ) and nominal exchange rates of 3.7 times $\mathrm{h}^{-1}$ (range $=2.8$ to 4.3 times $\left.\mathrm{h}^{-1}\right)$. Temperature $\left({ }^{\circ} \mathrm{C}\right)$ and salinity measurements were taken several times daily from seawater flowing into the aquaria. Seawater temperatures were not controlled, but followed the seasonal ambient seawater temperatures of the near-shore northeastern Gulf of Mexico.

Growth rates of red drum were calculated by subtracting the mean standard length (SL, $\mathrm{mm}$ ) of the fish from each diet treatment at the start of the experiment $\left(x_{\mathrm{S}}\right)$ from the individual SLs at the time each fish was sampled $\left(F_{n}\right)$ and divided by the number of days of treatment $\left(T_{n}\right)$, i.e.:

$$
\text { Growth rate }=\left(F_{n}-x_{\mathrm{s}}\right) / T_{n}
$$

$\boldsymbol{\delta}^{\mathbf{1 3}} \mathbf{C}$ values of the diets. A Finnigan Mat isotope ratio mass spectrometer (IRMS) was used to measure all stable isotope ratios by comparing the heavy:light element ratio in a sample relative to a known standard. Isotopic ratios are typically expressed using the 'del' $(\delta)$ notation with the general equation:

$$
\delta X(\% \text { o })=\left(R_{\text {sample }} / R_{\text {standard }}-1\right) \times 1000
$$

where $X$ is the sampled isotope ratio (e.g. ${ }^{13} \mathrm{C}:{ }^{12} \mathrm{C}$ ), $R_{\text {sample }}$ is the isotope ratio of the sample, and $R_{\text {standard }}$ is the isotope ratio of the standard. Random samples ( $\mathrm{n}=$ 4) were taken from the batch of AquaMax commercial feed during the course of the experiment. The AquaMax pellets were ground with a cleaned coffee grinder and a Crescent Wig-L-Bug. Processed samples were shipped to Isotope Services, in Los Alamos, New Mexico, for determination of the carbon stable isotopes.

Random samples of muscle tissue from each collection $(n=23)$ of pinfish were processed similar to the muscle tissue fed to the red drum; i.e. it was frozen, thawed, rinsed, and soaked in tap water. All bones and scales were removed. For sample analysis, the samples were then dried in an oven at $\sim 70^{\circ} \mathrm{C}$ for several days until the muscle was dry. The drying time varied for each individual muscle sample depending on amount. Upon removal from the oven, the tissue was ground into a fine, homogenous material with a Crescent Wig-L-Bug. Processed samples were shipped to Isotope Services. The 2 diets, commercial and pinfish 
muscle, differed significantly ( $t$-test, $\mathrm{p}<$ 0.001 ) in carbon isotopic composition by $2.12 \%$. The $\delta^{13} \mathrm{C}$ values of the commercial diet $(\mathrm{n}=4)$ had a mean $( \pm \mathrm{SD}) \delta^{13} \mathrm{C}$ of $-19.64 \pm 0.21 \%$. Because of the very small variation in the $\delta^{13} \mathrm{C}$ values, only 4 samples of the AquaMax diet were analyzed. The carbon isotopic values from the pinfish diet $(n=23)$ had a mean $\delta^{13} \mathrm{C}$ of $-17.52 \pm 1.62 \%$.

Seawater samples from the tanks were collected to measure the $\delta^{13} \mathrm{C}$ of DIC. Approximately $10 \mathrm{ml}$ of seawater from 3 randomly selected tanks were injected into pre-evacuated glass vials once each month. The vials were refrigerated until further processing. Approximately $0.2 \mathrm{ml}$ of $30 \%$ phosphoric acid was injected into each water sample. Head space $(\sim 0.2 \mathrm{ml})$ from the vials was then direct-injected into an IRMS at Florida State University.

Red drum were randomly sampled from each of the tanks on Days 160 and 261 of the experiment. On Day 160, 5 fish from each tank for a total of 20 fish from each diet treatment were randomly selected and measured. The fish were then overdosed with an anesthetic (MS-222) according to FSU Animal Care and Use Committee (ACUC) guidelines and frozen until further processing. All fish from 1 replicate in Treatment A died on Day 159 due to a malfunction in the aeration system and were used in the $160 \mathrm{~d}$ analysis. The remaining fish $(\mathrm{n}=34)$ were sampled on Day 261: 15 fish in Treatment A and 19 in Treatment B.

Experimental red drum were measured (SL, mm) and weighed (to nearest $0.1 \mathrm{~g}$ ), and a single fillet, minus bones and scales, was removed and weighed from each fish with the same precision. The muscle was then soaked in tap water for several minutes and dried at $\sim 70^{\circ} \mathrm{C}$ for several days. Muscle tissue was then ground to a fine powder with a Crescent Wig-L-Bug. Carbon isotope ratios were determined at Isotope Services.

Sagittal otoliths were extracted with forceps, rinsed in tap water, and cleansed with a paper towel to remove tissue adhering to the otoliths. Right and left otoliths were held separately in evacuation vials, then flushed with nitrogen gas and dissolved with $30 \%$ phosphoric acid. The samples were then analyzed for isotopic carbon on an IRMS at Florida State University.

Data analysis. ANOVA and a mixed model with a fixed effect for treatment and a random effect for the tank the fish were held in were used. The mixed effect model was coded using the R LME4 (www.r-project. org) statistical packages. Linear regressions were performed using either Microsoft Excel or Minitab
Treatment B: Pinfish

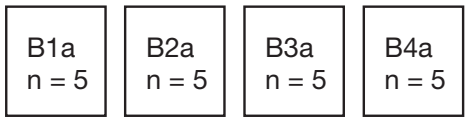

(V.2003). Grubbs test was used to test for outliers in the data set (Quinn \& Keough 2002). All significance levels were set at $\alpha=0.05$.

\section{RESULTS}

\section{Temperature and salinity of seawater}

The monthly mean temperature $( \pm \mathrm{SE})$ of the experimental tanks was $19.4 \pm 5.1^{\circ} \mathrm{C}$ (Fig. 2). The highest monthly mean temperatures $\left(26.9 \pm 2.2^{\circ} \mathrm{C}\right)$ were in June, on Day 260 , while the lowest $\left(13.7 \pm 3.8^{\circ} \mathrm{C}\right)$ were in January, on Day 120.

The mean daily salinity in the experimental tanks was $30.1 \pm 1.4$ (Fig. 2).

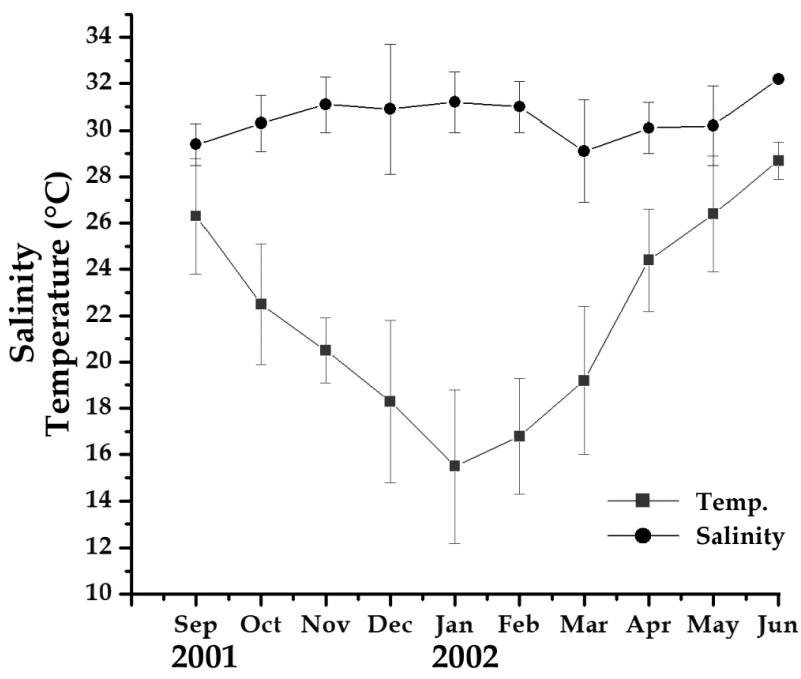

Fig. 2. Mean monthly temperature and salinity $( \pm \mathrm{SE})$ recordings at Florida State University Coastal and Marine Laboratory during the experiment 


\section{DIC isotopic composition}

The $\delta^{13} \mathrm{C}$ of DIC in the seawater was enriched relative to atmospheric $\mathrm{CO}_{2}(-8 \%)$ (Fig. 3). Monthly DIC isotopic compositions ranged from -4.82 to $-2.59 \%$ and had a mean $( \pm \mathrm{SE})$ of $-3.83 \pm 0.81 \%$. We did not observe a significant change in DIC values during the experiment (linear regression, $\mathrm{R}^{2}=0.18, \mathrm{p}=0.212$ ). There was no difference between spring/summer and fall/winter DIC isotope values either (ANOVA, $F=$ $0.735, \mathrm{p}=0.613$ ).

\section{Growth of red drum}

The red drum exhibited near-linear growth throughout the experiment (Fig. 4). On Day 160 of the experiment, 5 specimens were sampled from each of the remaining replicates of both treatments. The mean SL overall was $138.1 \mathrm{~mm}$ (SE: 16.1; range: 103 to $172 ; \mathrm{n}=$ 40). In fish sampled on Day 160 there was no significant difference ( $t$-test, $\mathrm{p}=0.43$ ) between the mean SL from Treatment A (140.1 mm; SE: 16.6; range: 104 to 172) and the mean SL from Treatment B (134.2 mm; SE: 18.0; range: 103 to 162 ).

The remaining fish, sampled on Day 261 of the experiment, had a combined mean SL of $203.1 \mathrm{~mm}$ (SE: 24.9; range: 140 to 250). For fish sampled on Day 261, there was no significant difference ( $t$-test, $\mathrm{p}=0.42)$ between the mean SL from Treatment A $(206.7 \mathrm{~mm}$; SE: 15.5; range: 177 to $239 ; \mathrm{n}=15)$ and Treatment $\mathrm{B}(200.2 \mathrm{~mm}$; SE: 30.5 ; range: 140 to $250 ; \mathrm{n}=19$ ).

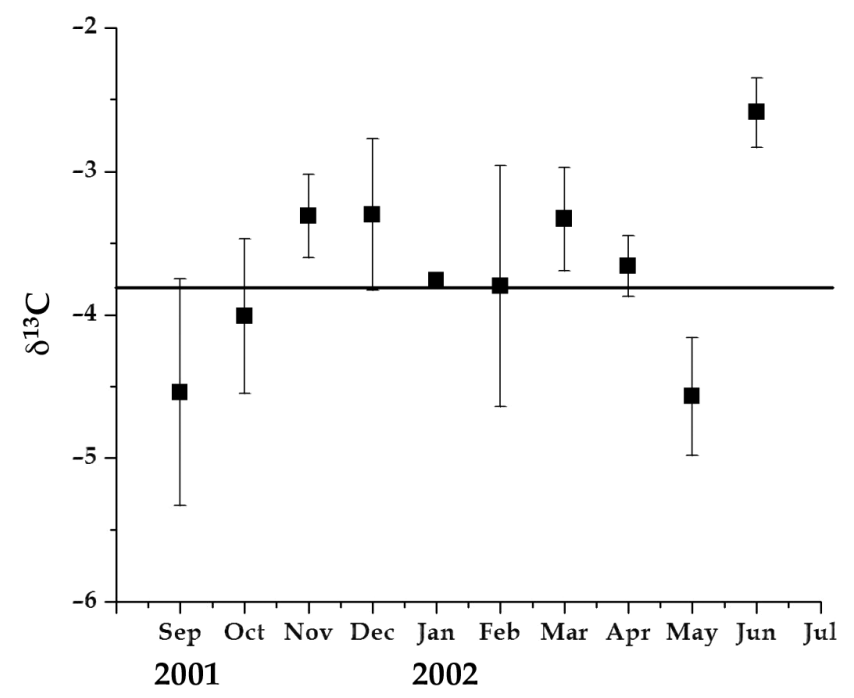

Fig. 3. Monthly carbon stable isotopic composition (mean $\pm \mathrm{SE}$ ) of the dissolved inorganic carbon (DIC) in seawater. The horizontal line represents the mean DIC $\delta^{13} \mathrm{C}$ value of $-3.83 \pm 0.81 \%$ o

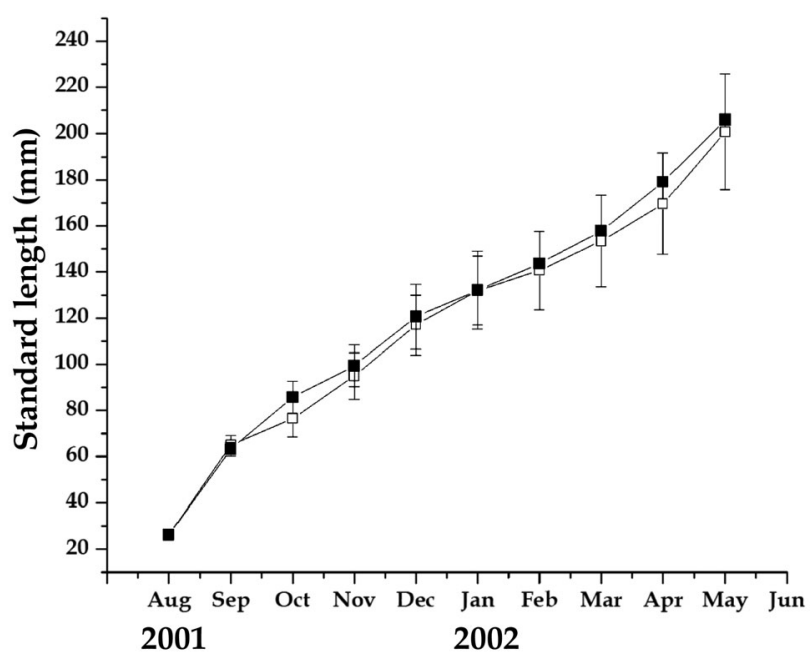

Fig. 4. Sciaenops ocellatus. Standard lengths of red drum from each diet treatment. $\mathbf{\square}$ : Treatment A, fish fed AquaMax; $\square$ : Treatment B, fish fed pinfish muscle

The mean growth rate of red drum from Treatment A $\left(0.51 \mathrm{~mm} \mathrm{~d}^{-1}\right.$; SE: 0.09$)$ was not significantly different (ANOVA, $p=0.88$ ) from the mean growth rate of fish from Treatment B $\left(0.49 \mathrm{~mm} \mathrm{~d}^{-1}\right.$; SE: 0.09). Growth rates calculated for the $160 \mathrm{~d}$ samples were not significantly different between treatments or among replicates (ANOVA, $\mathrm{p}=0.88$ ).

\section{Carbon isotopic composition of red drum muscle tissue}

Carbon isotope values of red drum muscle tissue were significantly different $(\mathrm{p}<0.001)$ between the 2 treatments (Fig. 5a). The mean $( \pm \mathrm{SD}) \delta^{13} \mathrm{C}$ of Treatment A muscle tissue was $-18.13 \pm 0.15(\mathrm{n}=32)$ and ranged from -18.36 to $-17.63 \%$. Tissue from Treatment $\mathrm{B}\left(\right.$ mean $\delta^{13} \mathrm{C}=-16.01 \pm 0.24 ; \mathrm{n}=38$ ) ranged from 16.49 to $-15.39 \%$. The difference in $\delta^{13} \mathrm{C}$ values between the 2 treatments was $2.12 \%$. Three outliers (Grubbs test; $\alpha=0.05$ ) from treatment A1a, A5b, and B4b with values of $-16.46,-16.29$, and $-16.88 \%$ were not included in the data set, and 1 muscle tissue sample from A4b was not processed.

Muscle tissue between the 2 diet treatments in both age classes was significantly different in isotopic value (Fig. 5a). Tissue from the fish in the short-duration experiment in Treatment A (mean $( \pm \mathrm{SD}) \delta^{13} \mathrm{C}=-18.18$ $\pm 0.10 \%$ o) were depleted $2.03 \%$ relative to their Treatment B counterparts (mean $\delta^{13} \mathrm{C}=-16.14 \pm 0.17 \%$ ), and that difference was significant (mixed-effects model, $\mathrm{p}<0.001$ ). Likewise, in the long-duration experiments fish from the 2 treatments had significantly different carbon isotopic values (mixed-effects model, $\mathrm{p}<0.001)$ where Treatment $\mathrm{A}\left(\right.$ mean $\delta^{13} \mathrm{C}=-18.06 \pm$ 

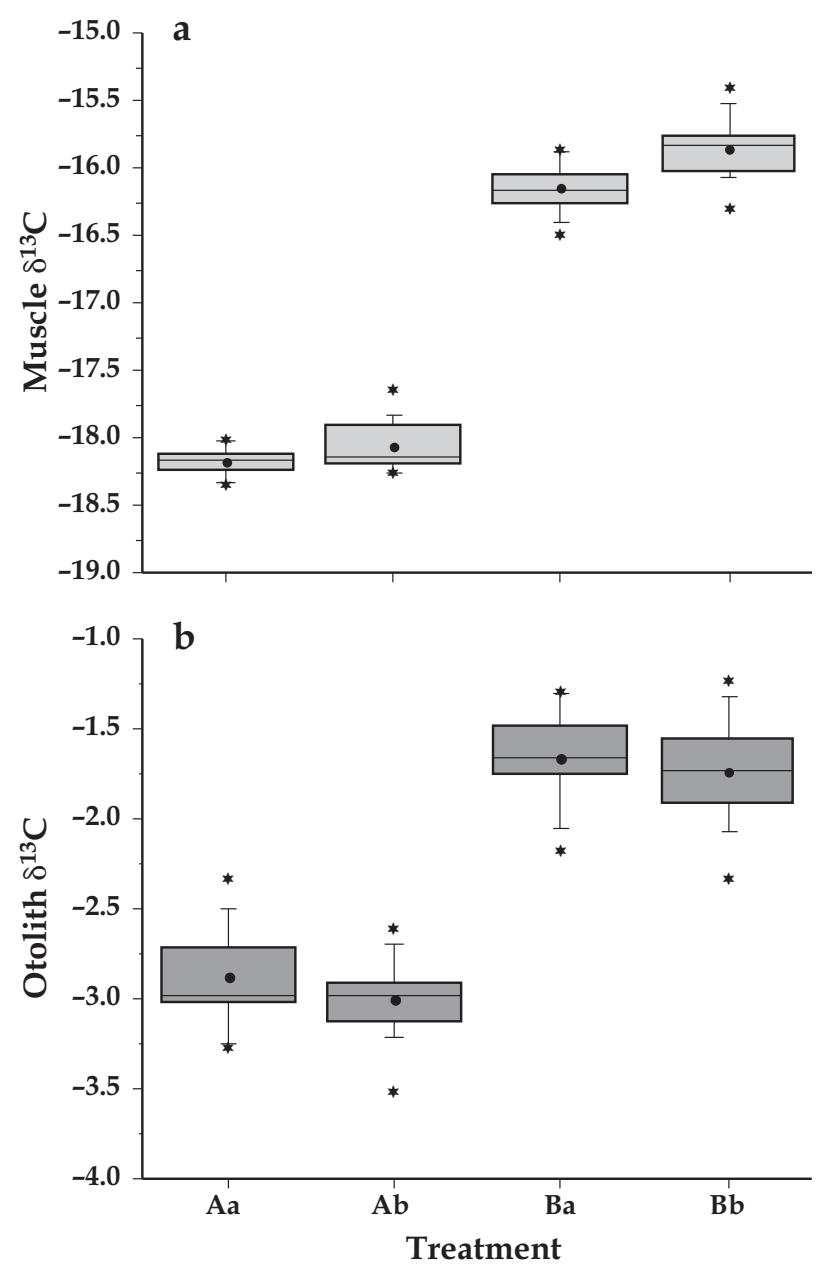

Fig. 5. Sciaenops ocellatus. Mean carbon isotopic composition of (a) muscle tissue and (b) otoliths from red drum fed different diets for short or long durations. Aa and Ab: AquaMax diet for 160 or $261 \mathrm{~d}$, respectively; Ba and Bb: minced pinfish

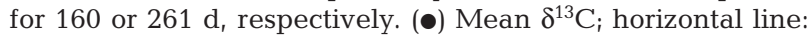
median; top and bottom of box: 1 SD from mean; whiskers: 25th and 75 th percentile; ${ }^{*}$ : data points below 25 th and above 75th quartile. See Fig. 1 for experimental setup

$0.20 \%$ ) was depleted $2.20 \%$ relative to Treatment B (mean $\delta^{13} \mathrm{C}=-15.86 \pm 0.21 \%$ ). Muscle tissue from both treatments was enriched by $1.51 \%$ relative to the respective diets.

\section{Carbon isotopic values of red drum otoliths}

The $\delta^{13} \mathrm{C}$ values were measured for the sagittal otolith pairs from both diet treatments and both experimental durations. The mean $( \pm \mathrm{SD}) \delta^{13} \mathrm{C}$ value for the pairs of otoliths from the red drum raised from Treatment $\mathrm{A}(\mathrm{n}=66)$ was $-2.94 \pm 0.23 \%$, with a range of -3.50 to $-2.44 \%$. Otoliths of fish from Treatment B ( $\mathrm{n}=76$ ) had a mean $\delta^{13} \mathrm{C}$ value of $-1.68 \pm 0.23 \%$ and a range of -2.19 to $-1.25 \%$. Two outliers from Treatment A (A1a-3,-1.29\%; A5b-4,-1.88\%) were not included in the otolith data set, and 1 outlier from Treatment B (B4b-2, $-2.93 \%$ ) was not included in the data (Grubbs test, $\alpha=0.05$ ). These were the same outliers from the muscle data, and it was presumed that they were a result of processing error (Fig. 5b). This difference of $1.26 \%$ between the 2 pooled means was significantly different (mixed-effects model, $\mathrm{p}<0.001$; Fig. 5b). Each otolith pair between the 2 diet treatments exhibited similar disparity.

The otoliths from both diet treatments were similarly enriched in ${ }^{13} \mathrm{C}$ with respect to the isotopic values of their diet and muscle tissue. The otolith $\delta^{13} \mathrm{C}$ values of fish in Treatment A were enriched by $16.70 \mathrm{ml}^{-1}$ and Treatment $B$ were enriched by $15.84 \mathrm{ml}^{-1}$ relative to the $\delta^{13} \mathrm{C}$ values of their respective diets. The otoliths from Treatment A were enriched $15.19 \%$ from the muscle carbon values, and Treatment B otoliths were enriched $14.33 \%$ with respect to the muscle tissue. These values were not significantly different (mixedeffects model, $\mathrm{p}=0.21$ ).

\section{DISCUSSION}

The results of this experiment and the experiments of others clearly demonstrate some influence of metabolically derived carbon on otolith $\delta^{13} \mathrm{C}$ value (Kalish 1991, Radtke et al. 1998b, Schwarcz et al. 1998, Høie et al. 2003, Solomon et al. 2006, Tohse \& Mugiya 2008). But, in order to properly interpret carbon stable isotope results for use in ecological studies, it is necessary to know the relative contribution of DIC and diet to the observed otolith $\delta^{13} \mathrm{C}$ value. To that end, studies with various fish species have demonstrated a dietary contribution ranging from 17 to $35 \%$ (Kalish 1991, Høie et al. 2003, Solomon et al. 2006, Tohse \& Mugiya 2008). Solomon et al. (2006), in a detailed experimental study on rainbow trout, estimated fractionation factors associated with otolith formation by manipulating the ambient water DIC $\delta^{13} \mathrm{C}$ and the dietary $\delta^{13} \mathrm{C}$ and, subsequently, by measuring the $\delta^{13} \mathrm{C}$ of the otolith, the endolymph DIC, and the blood DIC. They found that metabolic carbon accounted for $\sim 17 \%( \pm 3 \% \mathrm{SE})$ of the otolith $\delta^{13} \mathrm{C}$ value, while ambient DIC accounted for $>80 \%$. Also, they found a 2.7 to $3.6 \%$ net fractionation from the carbon sources to the otolith.

In our experiment, fish from both dietary treatments were held under the same water flow and DIC regimes and fed a diet that differed in isotopic content and nutritional characteristics. The mean difference in the $\delta^{13} \mathrm{C}$ of the diets was $2.12 \%$, and this difference was reflected in the muscle tissue (Fig. 5a). However, we observed a difference of only $1.26 \%$ between the 
mean $\delta^{13} \mathrm{C}$ values of the otoliths for both treatments (Fig. 5b). Otolith $\delta^{13} \mathrm{C}$ values ranged from -2.94 to $-1.68 \%$ between the 2 treatments and were only slightly enriched relative to the mean $\delta^{13} \mathrm{C}$ of seawater DIC, which was $-3.8 \pm 0.8 \%$. These differences from seawater DIC $\delta^{13} \mathrm{C}$ were caused by isotopic fractionation during carbonate incorporation into the otolith and by the admixture of respired carbon derived from diet. The similarity between ambient seawater DIC $\delta^{13} \mathrm{C}$ and the otolith $\delta^{13} \mathrm{C}$ of both treatments indicates that the bulk of the carbon making up the otoliths was derived from seawater DIC. It is difficult to rationalize then, how the relatively small difference in the diet $\delta^{13} \mathrm{C}$ value is expressed in the otoliths $(1.26 \%$, some $60 \%$ of the difference between the diet and tissue), since the contribution of diet to otolith carbon appears to be small. Possible explanations for the differences in the observed otolith $\delta^{13} \mathrm{C}$ between treatments include different degrees of fractionation at the gills or at the gut, or else food quality may have somehow influenced the otolith $\delta^{13} \mathrm{C}$ by changing the relative contribution of dietary $\delta^{13} \mathrm{C}$ relative to ambient DIC $\delta^{13} \mathrm{C}$.

To determine the percent contribution of food to the $\delta^{13} \mathrm{C}$ value of the otoliths from the observed results we used a simple 2 source mixing model, such that:

$$
\left(\delta_{\mathrm{DIC}} \times P_{\mathrm{DIC}}\right)+\left(\delta_{\mathrm{Food}} \times P_{\mathrm{Food}}\right)+\varepsilon=\delta_{\mathrm{OTO}}
$$

and

$$
P_{\text {DIC }}+P_{\text {Food }}=1
$$

where $\delta_{\text {DIC }}$ is the mean $\delta^{13} \mathrm{C}$ value of the DIC during the experiment, $\delta_{\text {Food }}$ is the mean $\delta^{13} \mathrm{C}$ value of the food, $P_{\text {DIC }}$ and $P_{\text {Food }}$ are the percent contribution of the DIC and food, respectively, to the final otolith $\delta^{13} \mathrm{C}$ value $\left(\delta_{\text {Ото }}\right)$, and $\varepsilon$ is the fractionation factor between the dissolved carbon sources and the final otolith $\delta^{13} \mathrm{C}$ value. Although we did not determine the fractionation factor independently we can use the values from Solomon et al. (2006) as a baseline to calculate the hypothetical values for the percent contribution of metabolic carbon to the diet. Because these fish are of the same species and were held under identical conditions, we assume that $\varepsilon$ should be the same in both treatments. The value of $\varepsilon$ based on the data by Solomon et al. (2006) is 3.15. Using Eqs. 3 \& 4 we calculate that the percent contributions of DIC $\delta^{13} \mathrm{C}$ and food $\delta^{13} \mathrm{C}$ to otolith $\delta^{13} \mathrm{C}$ were significantly different between treatments (mixed-effects model, $\mathrm{p}<0.00001)$. For Treatment $\mathrm{A}$, the mean $( \pm \mathrm{SD})$ contribution of DIC $\delta^{13} \mathrm{C}$ was $85 \%( \pm 1 \%)$ and the contribution of dietary $\delta^{13} \mathrm{C}$ was $15 \%( \pm 1 \%)$. For Treatment $\mathrm{B}$, the mean contribution of the $\delta^{13} \mathrm{C}$ value of DIC was $92 \%( \pm 2 \%)$ and the contribution of the food $\delta^{13} \mathrm{C}$ value was $8 \%( \pm 2 \%)$.

Given that both treatments were held under identical conditions, we suggest that the differences in the otolith $\delta^{13} \mathrm{C}$ values were caused by differences in the nutritional characteristics of the food that caused the pinfish-fed red drum (Treatment B) to incorporate more DIC-derived carbon into the otoliths. It seems unlikely that the fractionation from carbon sources would be different because conditions in the experiment were identical (same species, juveniles of the same size and age, same ambient water sources), except for the 2 food treatments. If this hypothesis is correct, then the nutritional characteristics of food may also affect otolith $\delta^{13} \mathrm{C}$ values, besides ambient water and food $\delta^{13} \mathrm{C}$. This would make calculating a universal or species value for the contribution of metabolic carbon to otoliths extremely difficult. Researchers who conduct experiments on the contribution of metabolic carbon to otolith $\delta^{13} \mathrm{C}$ values should consider varying the nutritional value of the experimental diet to determine if our hypothesis is correct.

Acknowledgements. This work was supported by the NOAANGI program and the Florida SeaGrant. The authors thank the FSUMCL staff for help with maintenance and animal care. We also thank Rachel Wilson for help with manuscript preparations.

\section{LITERATURE CITED}

Bastow TP, Jackson G, Edmonds JS (2002) Elevated salinity and isotopic composition of fish otolith carbonate: stock delineation of pink snapper, Pagras auratus, in Shark Bay, Western Australia. Mar Biol 141:801-806

Begg GA, Weidman CR (2001) Stable $\delta^{13} \mathrm{C}$ and $\delta^{18} \mathrm{O}$ isotopes in otoliths of haddock Melanogrammus aeglefinus from the northwest Atlantic Ocean. Mar Ecol Prog Ser 216: 223-233

> Das K, Lepoint G, Loizeau V, Debacker V, Dauby P, Bouquegneau JM (2000) Tuna and dolphin associations in the North-east Atlantic: evidence of different ecological niches from stable isotope and heavy metal measurements. Mar Pollut Bull 40:102-109

Degens ET, Deuser WG, Haedrich RL (1969) Molecular structure and composition of fish otoliths. Mar Biol 2:105-113

DeNiro MJ, Epstein S (1976) You are what you eat (plus a few per mil): the carbon isotope cycle in food chains. Geol Soc Am Abst Prog 8:834-835

Gao YW, Beamish RJ (1999) Isotopic composition of otoliths as a chemical tracer in population identification of sockeye salmon (Oncorhynchus nerka). Can J Fish Aquat Sci 56: 2062-2068

Høie H, Folkvord A, Otterlei E (2003) Effect of somatic and otolith growth rate on stable isotopic composition of early juvenile cod (Gadus morhua) otoliths. J Exp Mar Biol Ecol 289:41-58

> Høie H, Andersson C, Folkvord A, Karlsen O (2004) Precision and accuracy of stable isotope signals in otoliths of penreared cod (Gadus morhua) when sampled with a highresolution micromill. Mar Biol 144:1039-1049

> Kalish JM (1991) Oxygen and carbon stable isotopes in the otoliths of wild and laboratory-reared Australian salmon (Arripis-trutta). Mar Biol 110:37-47

$>$ Nelson JA, Chanton JP, Coleman FC, Koenig CC (2010) Patterns of stable carbon isotope turnover in gag, Myctero- 
perca microlepis, an economically important marine piscivore determined with a non-lethal surgical biopsy procedure. Environ Biol Fishes 90:243-252

Newman SJ, Steckis RA, Edmonds JS, Lloyd J (2000) Stock structure of the goldband snapper Pristipomoides multidens (pisces: Lutjanidae) from the waters of northern and western Australia by stable isotope ratio analysis of sagittal otolith carbonate. Mar Ecol Prog Ser 198:239-247

Quinn GP, Keough MJ (2002) Experimental design and data analysis for biologist. Cambridge University Press, Cambridge

Radtke RL, Showers W, Moksness E, Lenz P (1996) Environmental information stored in otoliths: insights from stable isotopes. Mar Biol 127:161-170

Radtke RL, Dempson JB, Ruzicka J (1998a) Microprobe analyses of anadromous arctic charr, Salvelinus alpinus, otoliths to infer life history migration events. Polar Biol 19:1-8

Editorial responsibility: Hans Heinrich Janssen, Oldendorf/Luhe, Germany
Radtke RL, Showers W, Moksness E, Lenz P (1998b) Corrigendum. Environmental information stored in otoliths: insights from stable isotopes (1996: Mar Biol 127161-170). Mar Biol 132:347-348

Schwarcz HP, Gao Y, Campana S, Browne D, Knyf M, Brand U (1998) Stable carbon isotope variations in otoliths of Atlantic cod (Gadus morhua). Can J Fish Aquat Sci 55:1798-1806

Solomon CT, Weber PK, Cech JJ, Ingram BL and others (2006) Experimental determination of the sources of otolith carbon and associated isotopic fractionation. Can J Fish Aquat Sci 63:79-89

Tohse H, Mugiya Y (2008) Sources of otolith carbonate: experimental determination of carbon incorporation rates from water and metabolic $\mathrm{CO}_{2}$, and their diel variations. Aquat Biol 1:259-268

Weidman CR, Millner R (2000) High-resolution isotope records from North Atlantic cod. Fish Res 46:327-342

Submitted: October 11, 2010; Accepted: May 9, 2011 Proofs received from author(s): July 7, 2011 